2016-04

\title{
Achieving cost and carbon savings in neonatal practice: A review of the literature on sustainable waste
} management

Nichols, Andrew

http://hdl.handle.net/10026.1/10149

10.1016/j.jnn.2016.01.002

Journal of Neonatal Nursing

Elsevier BV

All content in PEARL is protected by copyright law. Author manuscripts are made available in accordance with publisher policies. Please cite only the published version using the details provided on the item record or document. In the absence of an open licence (e.g. Creative Commons), permissions for further reuse of content should be sought from the publisher or author. 
This is the author's accepted manuscript. The final published version of this work (the version of record) is published by Elsevier in the Journal of Neonatal Nursing in April 2016 available at: https://doi.org/10.1016/j.jnn.2016.01.002 [DOI]. This work is made available online in accordance with the publisher's policies. Please refer to any applicable terms of use of the publisher."

Achieving cost and carbon savings in neonatal practice: A review of the literature on sustainable waste management

\begin{abstract}
Sustainable waste management in neonatal and high dependency care areas has not been given sufficient priority or consideration according to literature. As a consequence research is lacking in identifying waste that may be recyclable or reduced, generating income that could be reinvested in patient care. The key aim of this paper is to explore and report on the systematic review of the literature, which discloses waste management practice within neonatal and high dependency care areas, which may identify waste with subsequent environmental impacts. Exclusion criteria, inclusion criteria and search by terms methodologies were used to carry the systematic review essential for the study. The research findings suggest that there is little published material on waste management within neonatology or other high dependency and resource dependent clinical areas. This lack of published material could be seen as an indication that this is a relatively unexplored area of clinical practice that provides an opportunity for further empirical research and development of interventions within highly resource dependent areas such as neonatal intensive care that are intended to reduce waste costs and carbon emissions whilst promoting a sustainable reduce, re-use, recycle philosophy within healthcare waste management.
\end{abstract}

\title{
Keywords
}

Waste. Sustainability. Literature review. 


\section{Introduction}

The importance of wisely using and conserving scarce and costly resources within healthcare has been well reported in the literature (Richardson et al 2009; Nichols 2014) as has the need for healthcare organisations such as the National Health Service (NHS) to reduce their waste and their subsequent environmental impact on society (Manzi et al 2014). The NHS in the United Kingdom (UK) has been reported to have had a carbon footprint of approximately 21 million tonnes of CO2E in 2011/12 and has been tasked with significantly reducing this carbon footprint by 2020 (NHS Sustainable Development Unit 2012). A significant element of this carbon footprint is generated by transport and management of waste.

In addition to environmental costs, the financial costs of healthcare waste management must also be considered. The Royal College of Nursing (RCN) (2011) in their investigation of waste management found that organisations participating in their study during $2009-10$ produced waste costing approximately $£ 65,500,000$. The RCN go on to claim that a $20 \%$ reduction in infectious waste could produce a yearly saving of around $£ 8,840,000$ in waste management processing costs. More broadly, the Academy of Medical Royal Colleges (AOMRC) (2014) has argued that avoiding waste and promoting value in healthcare is associated with quality of care. This is arguably particularly pertinent for clinical areas that are highly dependent on scarce, specialist resources and at times when resources are constrained (AOMRC 2014). In the face of increasing constraints on funds and resources, which may have a particular impact on high dependency, high resource consuming areas such as intensive care, waste must be reduced and available resources used wisely (AOMRC 2014; Nichols 2014). However, there is evidence within the literature that reducing waste generated in clinical care has not been given sufficient priority or consideration (AOMRC 2014). Furthermore, evidence also suggests that significant proportions of waste generated within high dependency areas may be recyclable thus potentially generating income that could be reinvested in patient care. In addition, it has been argued that research into the reduction and management of waste in high dependency areas such as intensive care and neonatal intensive care is lacking (McGain et al 2010).

This evidence indicates the need for some further investigation of the management of waste within high dependency and resource dependent areas such as neonatal intensive care. This paper reports on a systematic review of the literature with the intention of investigating waste management within healthcare with an in initial 
specific focus upon neonatology, as this area has been identified as being especially dependent on the availability of resources and technology and may consequently generate significant amounts of waste with subsequent environmental impacts (Nichols 2013;2014).

\section{Methods}

A systematic review of the literature was carried out with an initial aim of identifying contemporary and recently published empirical research or policy documents within neonatology relating to clinical waste. Appropriate databases (Table 1) were searched (January 2015) to identify relevant research published in English.

\section{Inclusion criteria}

Inclusion criteria were that the article title, abstract and body of original research papers, policy documents, professional body / organisation documents, published and unpublished (grey literature) appeared to be relevant to the research topic. Papers must have been published or if "grey literature" produced after the year 2000, in English.

\section{Exclusion criteria}

Letters, newspaper articles, opinion pieces and non-academic documents were excluded.

\section{Search terms}

An initial search was carried out using the search terms: "clinical waste" OR "health* waste" AND neonatology OR paediatric intensive care. In this first search a total of 1241 papers that could be potentially included in the review were identified. When further studied all but 1 paper were rejected as they did not fit the requirements of the literature review. Following this a second search was carried out, this search was extended to include a broader category of high dependency areas and general paediatric care including search terms such as "intensive care" "paediatric" and "adult". This second search revealed a further 599 papers that were potentially suitable for inclusion in the review. However, on further scrutiny all of these papers were also rejected as their content did fit with the aims of the literature review.

Despite extensive and iterative searching of databases using the above criteria only one paper was found relating to healthcare waste and neonatology or paediatric intensive care: Nichols A (2013) Sustainable family centred care in the neonatal Unit. Journal of Neonatal Nursing. These results prompted discussion with the research team and a third, final search of the literature was undertaken. The third search of the literature used the same inclusion and exclusion criteria as the previous two searches. This search returned to the focus on general paediatrics using AND instead of OR for intensive care. This was an attempt to reduce the risk of any relevant publications being missed by the search, 1891 abstracts were identified for further review but once again no papers were considered relevant for inclusion

Searches carried out and search terms used: 
1. "clinical waste" OR "health* waste" AND neonatology OR paediatric intensive care

2. "clinical waste" OR "health* waste" AND Paediatrics OR "intensive care" OR Adult

3. "clinical waste" OR "health* waste" AND "intensive care" AND Paediatrics

The flow chart and tables 1 to 3 below indicate how the literature search was carried out and how the search terms used in the literature review were extended in each search phase.

\section{Flow chart}

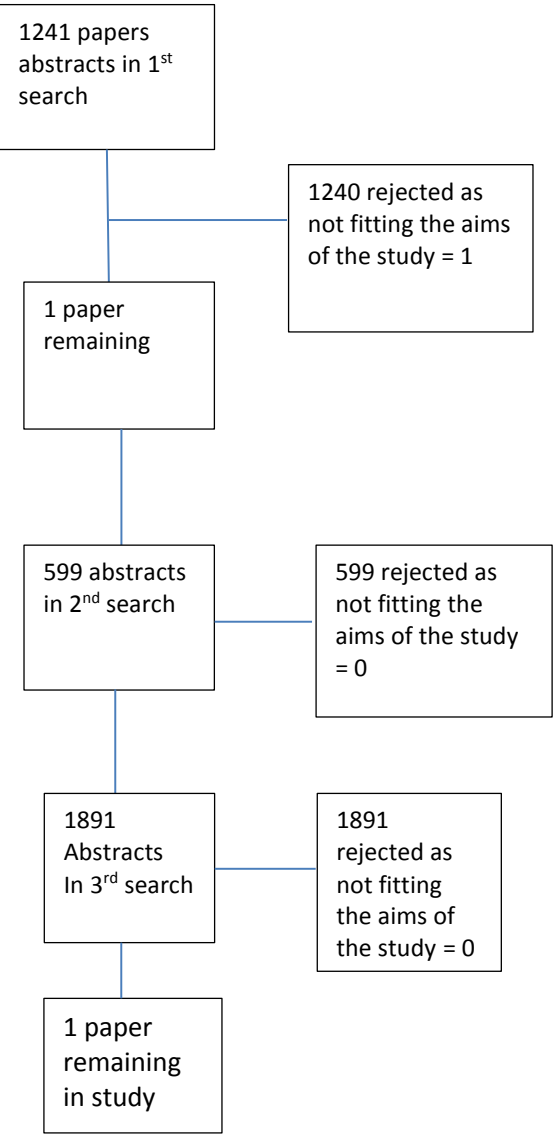


Table 1: Results of the literature search (search 1)

The following databases were searched with the results shown

\begin{tabular}{|c|c|c|c|c|c|}
\hline Database & $\begin{array}{l}\text { Search } \\
\text { terms }\end{array}$ & Inclusion & Exclusion & Additions & Results \\
\hline Primo & $\begin{array}{l}\text { "clinical waste" } \\
\text { OR "health" } \\
\text { waste" }\end{array}$ & $\begin{array}{l}2000-2015 \\
\text { All items }\end{array}$ & $\begin{array}{l}\text { In English } \\
\text { Journals }\end{array}$ & $\begin{array}{l}\text { AND neonatology } \\
\text { OR paediatric } \\
\text { intensive care }\end{array}$ & $\begin{array}{l}=30 \text { reviewed } 1 \\
\text { kept } *\end{array}$ \\
\hline Ebsco ovid & $\begin{array}{l}\text { "health* waste" } \\
\text { OR "clinical } \\
\text { waste" }\end{array}$ & $\begin{array}{l}2000-2015 \\
\text { All items }\end{array}$ & $\begin{array}{l}\text { In English } \\
\text { Journals }\end{array}$ & $\begin{array}{l}\text { AND neonatology } \\
\text { OR paediatric } \\
\text { intensive care }\end{array}$ & $\begin{array}{l}=250 \\
0 \text { kept }\end{array}$ \\
\hline PubMed & $\begin{array}{l}\text { "health* waste" } \\
\text { OR "clinical } \\
\text { waste" }\end{array}$ & $\begin{array}{l}2000-2015 \\
\text { All items }\end{array}$ & $\begin{array}{l}\text { In English } \\
\text { Journals }\end{array}$ & $\begin{array}{l}\text { AND neonatology } \\
\text { OR paediatric } \\
\text { intensive care }\end{array}$ & $=0$ \\
\hline $\begin{array}{l}\text { Ebsco } \\
\text { Medline }\end{array}$ & $\begin{array}{l}\text { "health" waste" } \\
\text { OR "clinical } \\
\text { waste" }\end{array}$ & $\begin{array}{l}2000-2015 \\
\text { All items }\end{array}$ & $\begin{array}{l}\text { In English } \\
\text { Journals }\end{array}$ & $\begin{array}{l}\text { AND neonatology } \\
\text { OR paediatric } \\
\text { intensive care }\end{array}$ & $\begin{array}{l}=820 \text { about } \mathrm{PIC} \\
\text { only so } \mathrm{PIC} \\
\text { removed }=0\end{array}$ \\
\hline $\begin{array}{l}\text { Web of } \\
\text { science }\end{array}$ & $\begin{array}{l}\text { "health" waste" } \\
\text { OR "clinical } \\
\text { waste" }\end{array}$ & $\begin{array}{l}2000-2015 \\
\text { All items }\end{array}$ & $\begin{array}{l}\text { In English } \\
\text { Journals }\end{array}$ & $\begin{array}{l}\text { AND neonatology } \\
\text { OR paediatric } \\
\text { intensive care }\end{array}$ & $=0$ \\
\hline Cochrane & $\begin{array}{l}\text { "health" waste" } \\
\text { OR "clinical } \\
\text { waste" }\end{array}$ & $\begin{array}{l}2000-2015 \\
\text { All items }\end{array}$ & $\begin{array}{l}\text { In English } \\
\text { Journals }\end{array}$ & $\begin{array}{l}\text { AND neonatology } \\
\text { OR paediatric } \\
\text { intensive care }\end{array}$ & $\begin{array}{l}6 \text { reviewed } 0 \\
\text { kept }\end{array}$ \\
\hline $\begin{array}{l}\text { Biomed } \\
\text { central }\end{array}$ & $\begin{array}{l}\text { "health* waste" } \\
\text { "clinical waste" }\end{array}$ & $\begin{array}{l}2000-2015 \\
\text { All items }\end{array}$ & $\begin{array}{l}\text { In English } \\
\text { Journals }\end{array}$ & $\begin{array}{l}\text { AND neonatology } \\
\text { OR paediatric } \\
\text { intensive care }\end{array}$ & $=0$ \\
\hline BMJ & $\begin{array}{l}\text { "health* waste" } \\
\text { OR "clinical } \\
\text { waste" }\end{array}$ & $\begin{array}{l}2000-2015 \\
\text { All items }\end{array}$ & $\begin{array}{l}\text { In English } \\
\text { Journals }\end{array}$ & $\begin{array}{l}\text { AND neonatology } \\
\text { OR paediatric } \\
\text { intensive care }\end{array}$ & $=0$ \\
\hline Greenfile & $\begin{array}{l}\text { "health" waste" } \\
\text { OR "clinical } \\
\text { waste" }\end{array}$ & $\begin{array}{l}2000-2015 \\
\text { All items }\end{array}$ & $\begin{array}{l}\text { In English } \\
\text { Journals }\end{array}$ & $\begin{array}{l}\text { AND neonatology } \\
\text { OR paediatric } \\
\text { intensive care }\end{array}$ & $\begin{array}{l}=\quad 38 \quad \text { about } \\
\text { clinical waste } \\
\text { management } \\
\text { only }=0 \text { kept }\end{array}$ \\
\hline $\begin{array}{l}\text { Science } \\
\text { Direct }\end{array}$ & $\begin{array}{l}\text { "health* waste" } \\
\text { OR "clinical } \\
\text { waste" }\end{array}$ & $\begin{array}{l}2000-2015 \\
\text { All items }\end{array}$ & $\begin{array}{l}\text { In English } \\
\text { Journals }\end{array}$ & $\begin{array}{l}\text { AND neonatology } \\
\text { OR paediatric } \\
\text { intensive care }\end{array}$ & $\begin{array}{l}=97 \text { reviewed }= \\
1 \text { kept }^{*}\end{array}$ \\
\hline $\begin{array}{l}\text { Joanna } \\
\text { Briggs }\end{array}$ & $\begin{array}{l}\text { "health" waste" } \\
\text { OR "clinical } \\
\text { waste" }\end{array}$ & $\begin{array}{l}2000-2015 \\
\text { All items }\end{array}$ & $\begin{array}{l}\text { In English } \\
\text { Journals }\end{array}$ & $\begin{array}{l}\text { AND neonatology } \\
\text { OR paediatric } \\
\text { intensive care }\end{array}$ & $=0$ \\
\hline
\end{tabular}

Table 2: Results of the literature (search 2) 


\begin{tabular}{|c|c|c|c|c|c|c|}
\hline Database & Search & terms & Inclusion & Exclusion & Additions & Results \\
\hline Primo & $\begin{array}{l}\text { "clinical } \\
\text { OR } \\
\text { waste" }\end{array}$ & $\begin{array}{c}\text { waste" } \\
\text { "health" }\end{array}$ & $\begin{array}{l}2000-2015 \\
\text { All items }\end{array}$ & $\begin{array}{l}\text { In English } \\
\text { Journals }\end{array}$ & $\begin{array}{ll}\text { AND } & \text { Paediatrics } \\
\text { OR } & \text { "intensive } \\
\text { care" } & \text { OR Adult }\end{array}$ & $\begin{array}{l}18 \text { found }=0 \\
\text { relevant }\end{array}$ \\
\hline Ebsco ovid & $\begin{array}{l}\text { "clinical } \\
\text { OR } \\
\text { waste" }\end{array}$ & $\begin{array}{c}\text { waste" } \\
\text { "health* }\end{array}$ & $\begin{array}{l}2000-2015 \\
\text { All items }\end{array}$ & $\begin{array}{l}\text { In English } \\
\text { Journals }\end{array}$ & $\begin{array}{ll}\text { AND } & \text { Paediatrics } \\
\text { OR } & \text { "intensive } \\
\text { care" } & \text { OR Adult }\end{array}$ & $4=0$ \\
\hline PubMed & \begin{tabular}{|l|} 
"clinical \\
OR \\
waste" \\
\end{tabular} & $\begin{array}{l}\text { waste" } \\
\text { "health* }\end{array}$ & $\begin{array}{l}2000-2015 \\
\text { All items }\end{array}$ & $\begin{array}{l}\text { In English } \\
\text { Journals }\end{array}$ & $\begin{array}{ll}\text { AND } & \text { Paediatrics } \\
\text { OR "intensive } \\
\text { care" OR Adult }\end{array}$ & $0=0$ \\
\hline $\begin{array}{l}\text { Ebsco } \\
\text { Medline }\end{array}$ & $\begin{array}{l}\text { "clinical } \\
\text { OR } \\
\text { waste" }\end{array}$ & $\begin{array}{c}\text { waste" } \\
\text { "health" }\end{array}$ & $\begin{array}{l}2000-2015 \\
\text { All items }\end{array}$ & $\begin{array}{l}\text { In English } \\
\text { Journals }\end{array}$ & $\begin{array}{ll}\text { AND } & \text { Paediatrics } \\
\text { OR } & \text { "intensive } \\
\text { care" } & \text { OR Adult }\end{array}$ & $17=0$ \\
\hline $\begin{array}{l}\text { Web of } \\
\text { science }\end{array}$ & $\begin{array}{l}\text { "clinical } \\
\text { OR } \\
\text { waste" }\end{array}$ & $\begin{array}{c}\text { waste" } \\
\text { "health* }\end{array}$ & $\begin{array}{l}2000-2015 \\
\text { All items }\end{array}$ & $\begin{array}{l}\text { In English } \\
\text { Journals }\end{array}$ & $\begin{array}{l}\text { AND Paediatrics } \\
\text { OR "intensive } \\
\text { care" OR Adult }\end{array}$ & $28=0$ \\
\hline Cochrane & $\begin{array}{l}\text { "clinical } \\
\text { OR } \\
\text { waste" }\end{array}$ & $\begin{array}{c}\text { waste" } \\
\text { "health" }\end{array}$ & $\begin{array}{l}2000-2015 \\
\text { All items }\end{array}$ & $\begin{array}{l}\text { In English } \\
\text { Journals }\end{array}$ & $\begin{array}{ll}\text { AND } & \text { Paediatrics } \\
\text { OR "intensive } \\
\text { care" OR Adult }\end{array}$ & $0=0$ \\
\hline $\begin{array}{l}\text { Biomed } \\
\text { central }\end{array}$ & $\begin{array}{l}\text { "clinical } \\
\text { OR } \\
\text { waste" } \\
\end{array}$ & $\begin{array}{l}\text { waste" } \\
\text { "health* }\end{array}$ & $\begin{array}{l}2000-2015 \\
\text { All items }\end{array}$ & $\begin{array}{l}\text { In English } \\
\text { Journals }\end{array}$ & $\begin{array}{ll}\text { AND } & \text { Paediatrics } \\
\text { OR } & \text { "intensive } \\
\text { care" OR Adult }\end{array}$ & $2=0$ \\
\hline BMJ & $\begin{array}{l}\text { "clinical } \\
\text { OR } \\
\text { waste" }\end{array}$ & $\begin{array}{c}\text { waste" } \\
\text { "health" }\end{array}$ & $\begin{array}{l}2000-2015 \\
\text { All items }\end{array}$ & $\begin{array}{l}\text { In English } \\
\text { Journals }\end{array}$ & $\begin{array}{ll}\text { AND } & \text { Paediatrics } \\
\text { OR } & \text { "intensive } \\
\text { care" } & \text { OR Adult }\end{array}$ & $0=0$ \\
\hline Greenfile & $\begin{array}{l}\text { "clinical } \\
\text { OR } \\
\text { waste" }\end{array}$ & $\begin{array}{c}\text { waste" } \\
\text { "health" }\end{array}$ & $\begin{array}{l}2000-2015 \\
\text { All items }\end{array}$ & $\begin{array}{l}\text { In English } \\
\text { Journals }\end{array}$ & $\begin{array}{ll}\text { AND } & \text { Paediatrics } \\
\text { OR } & \text { "intensive } \\
\text { care" } & \text { OR Adult }\end{array}$ & $210=0$ \\
\hline $\begin{array}{l}\text { Science } \\
\text { Direct }\end{array}$ & $\begin{array}{l}\text { "clinical } \\
\text { OR } \\
\text { waste" }\end{array}$ & $\begin{array}{c}\text { waste" } \\
\text { "health" }\end{array}$ & $\begin{array}{l}2000-2015 \\
\text { All items }\end{array}$ & $\begin{array}{l}\text { In English } \\
\text { Journals }\end{array}$ & $\begin{array}{l}\text { AND Paediatrics } \\
\text { OR "intensive } \\
\text { care" OR Adult }\end{array}$ & $320=0$ \\
\hline $\begin{array}{l}\text { Joanna } \\
\text { Briggs }\end{array}$ & $\begin{array}{l}\text { "clinical } \\
\text { OR } \\
\text { waste" }\end{array}$ & $\begin{array}{c}\text { waste" } \\
\text { "health" }\end{array}$ & $\begin{array}{l}2000-2015 \\
\text { All items }\end{array}$ & $\begin{array}{l}\text { In English } \\
\text { Journals }\end{array}$ & $\begin{array}{ll}\text { AND } & \text { Paediatrics } \\
\text { OR "intensive } \\
\text { care" OR Adult }\end{array}$ & $0=0$ \\
\hline
\end{tabular}


Table 3: Results of the literature (search 3)

\begin{tabular}{|c|c|c|c|c|c|}
\hline Database & Search terms & Inclusion & Exclusion & Additions & Results \\
\hline Primo & $\begin{array}{ll}\text { "clinical } & \text { waste" } \\
\text { OR } & \text { "health* } \\
\text { waste" } & \\
\end{array}$ & $\begin{array}{l}2000-2015 \\
\text { All items }\end{array}$ & $\begin{array}{l}\text { In English } \\
\text { Journals }\end{array}$ & $\begin{array}{lr}\text { AND } & \text { "intensive } \\
\text { care" } & \text { AND } \\
\text { Paediatrics } & \end{array}$ & $\begin{array}{l}578 \text { found }= \\
0 \text { relevant }\end{array}$ \\
\hline Ebsco ovid & $\begin{array}{ll}\text { "clinical } & \text { waste" } \\
\text { OR } & \text { "health* } \\
\text { waste" } & \end{array}$ & $\begin{array}{l}2000-2015 \\
\text { All items }\end{array}$ & $\begin{array}{l}\text { In English } \\
\text { Journals }\end{array}$ & $\begin{array}{lr}\text { AND } & \text { "intensive } \\
\text { care" } & \text { AND } \\
\text { Paediatrics } & \end{array}$ & $424=0$ \\
\hline PubMed & $\begin{array}{ll}\text { "clinical } & \text { waste" } \\
\text { OR } & \text { "health* } \\
\text { waste" } & \\
\end{array}$ & $\begin{array}{l}2000-2015 \\
\text { All items }\end{array}$ & $\begin{array}{l}\text { In English } \\
\text { Journals }\end{array}$ & $\begin{array}{lr}\text { AND } & \text { "intensive } \\
\text { care" } & \text { AND } \\
\text { Paediatrics } & \\
\end{array}$ & $0=0$ \\
\hline $\begin{array}{l}\text { Ebsco } \\
\text { Medline }\end{array}$ & 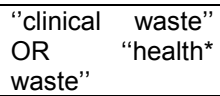 & $\begin{array}{l}2000-2015 \\
\text { All items }\end{array}$ & $\begin{array}{l}\text { In English } \\
\text { Journals }\end{array}$ & $\begin{array}{l}\text { AND "intensive } \\
\text { care" } \\
\text { Paediatrics }\end{array}$ & $326=0$ \\
\hline $\begin{array}{l}\text { Web of } \\
\text { science }\end{array}$ & $\begin{array}{ll}\text { "clinical } & \text { waste" } \\
\text { OR } & \text { "health* } \\
\text { waste" } & \\
\end{array}$ & $\begin{array}{l}2000-2015 \\
\text { All items }\end{array}$ & $\begin{array}{l}\text { In English } \\
\text { Journals }\end{array}$ & $\begin{array}{lr}\text { AND } & \text { "intensive } \\
\text { care" } & \text { AND } \\
\text { Paediatrics } & \\
\end{array}$ & $218=0$ \\
\hline Cochrane & $\begin{array}{ll} & \text { "clinical waste" } \\
\text { OR } & \text { "health* } \\
\text { waste" } & \end{array}$ & $\begin{array}{l}2000-2015 \\
\text { All items }\end{array}$ & $\begin{array}{l}\text { In English } \\
\text { Journals }\end{array}$ & $\begin{array}{l}\text { AND "intensive } \\
\text { care" } \\
\text { Paediatrics }\end{array}$ & $0=0$ \\
\hline $\begin{array}{l}\text { Biomed } \\
\text { central }\end{array}$ & $\begin{array}{ll}\text { "clinical waste" } & \text { "wealth* } \\
\text { OR } & \text { "heaste" }\end{array}$ & $\begin{array}{l}2000-2015 \\
\text { All items }\end{array}$ & $\begin{array}{l}\text { In English } \\
\text { Journals }\end{array}$ & $\begin{array}{lr}\text { AND "intensive } \\
\text { care" } \\
\text { Paediatrics }\end{array}$ & $0=0$ \\
\hline BMJ & $\begin{array}{ll}\text { "clinical } & \text { waste" } \\
\text { OR } & \text { "health* } \\
\text { waste" } & \\
\end{array}$ & $\begin{array}{l}2000-2015 \\
\text { All items }\end{array}$ & $\begin{array}{l}\text { In English } \\
\text { Journals }\end{array}$ & $\begin{array}{lr}\text { AND "intensive } \\
\text { care" } \\
\text { Paediatrics }\end{array}$ & $0=0$ \\
\hline Greenfile & $\begin{array}{ll} & \text { "clinical waste" } \\
\text { OR } & \text { "health* } \\
\text { waste" } & \end{array}$ & $\begin{array}{l}2000-2015 \\
\text { All items }\end{array}$ & $\begin{array}{l}\text { In English } \\
\text { Journals }\end{array}$ & $\begin{array}{l}\text { AND "intensive } \\
\text { care" } \\
\text { Paediatrics }\end{array}$ & $0=0$ \\
\hline $\begin{array}{l}\text { Science } \\
\text { Direct }\end{array}$ & $\begin{array}{ll}\text { "clinical } & \text { waste" } \\
\text { OR } & \text { "health* } \\
\text { waste" } & \\
\end{array}$ & $\begin{array}{l}2000-2015 \\
\text { All items }\end{array}$ & $\begin{array}{l}\text { In English } \\
\text { Journals }\end{array}$ & $\begin{array}{lr}\text { AND } & \text { "intensive } \\
\text { care" } & \text { AND } \\
\text { Paediatrics } & \\
\end{array}$ & $345=0$ \\
\hline $\begin{array}{l}\text { Joanna } \\
\text { Briggs }\end{array}$ & $\begin{array}{ll}\text { "clinical } & \text { waste" } \\
\text { OR } & \text { "health* } \\
\text { waste" } & \\
\end{array}$ & $\begin{array}{l}2000-2015 \\
\text { All items }\end{array}$ & $\begin{array}{l}\text { In English } \\
\text { Journals }\end{array}$ & $\begin{array}{l}\text { AND "intensive } \\
\text { care", } \\
\text { Paediatrics }\end{array}$ & $0=0$ \\
\hline
\end{tabular}

\section{Discussion}

The results of this literature review clearly support the argument that little consideration has been given to the management of waste generated within clinical settings (AOMRC 2014) and that little published research has been carried out investigating waste management within high dependency and resource dependent areas such as neonatal intensive care units (McGain et al 2010). Having carried out an iterative and exhaustive search of the literature, it is difficult to contradict the arguments of McGain (2010) and the AOMRC (2014) and it could be concluded that this is an area worthy of further investigation and development of interventions that might reduce waste costs and emissions and may even lead to income generation through greater use of recycling.

There is evidence to support the suggestion that intensive care areas such as NNU are expensive to operate and may be particularly resource dependent. NICE (2010) in their discussion of neonatal care costs, commissioning, quality and standards 
were clear that in 2008/09 the national average daily unit cost of intensive care was more than double that of special care. Luchetti (2013) agrees with NICE arguing that intensive care generally is one of medicines most expensive specialities. Luchetti (2013) goes on to claim that within intensive care in Europe resource use is often inefficient and argues it is essential that resources are used carefully and appropriately. Seidel et al (2006) concur with Luchetti (2013) arguing that in light of increasing financial constraints within healthcare, clinicians should utilise resources responsibly. Arguably however, the allocation, management and utilisation of resources within areas such as NNU should be the concern of all stakeholders clinicians, managers, support staff and the families/carers of NNU patients, as these resources are expensive, finite (Seidel et al 2006; Wilkinson 2013) and too valuable to waste. The issue of cost is raised by Wilkinson (2013) who argues that cost should be a major concern when making decisions relating to neonatal intensive care and that a utilitarian approach should be adopted to ensure that resources are not wasted and are instead used wisely to provide the greatest benefit for the greatest number in need. It is perhaps surprising then that despite the evidence in the literature supporting the notion that intensive care is expensive, particularly resource dependent and potentially inefficient and wasteful in its use of these resources that there is also clear evidence suggesting that little investigation into resource and waste management in intensive care areas has been carried out (Welton et al 2002; McGain et al 2010; AOMRC 2014).

Arguably, high dependency and the consumption of resources and materials associated with patient care must lead to significant generation of waste with the subsequent costs associated with its management. The RCN (2011) have given some indication of the high cost of healthcare waste management generally and are also able to give an estimate of the difference in the costs of clinical or "infectious waste" and domestic waste, finding that per tonne the management of "infectious" clinical waste costs around three times that of domestic waste. For NNU this may well be significant as problems with the correct segregation of waste have been reported in the literature with Nichols (2014) finding that compromised NNU environments may reduce the ability of NNU staff to effectively segregate waste at the point generation, with the result that domestic waste is disposed of via the more expensive clinical waste stream thus attracting waste management costs that may be up to three times higher than required. This is arguably an area that requires further investigation. By reducing waste, ensuring its correct segregation at the point of its generation, disposal via the correct waste stream and recycling where possible, cost savings and income generation might be achieved, thus waste itself may be seen as a resource to be exploited (Manzi et al 2014).

The claimed lack of research in this area is to some extent supported by Manzi et al (2014) who similarly to McGain et al ( 2010) and AOMRC (2014) found a virtual absence of waste focussed research within health and social care settings, supporting the notion that this is an under investigated area. Manzi et al (2014) also 
argue that making evidence based improvements in healthcare waste management may be of some appeal to healthcare organisations as such improvements may potentially enable rapid positive changes and reduce costs without directly impacting on patient care. However, there is evidence within the literature suggesting that healthcare organisations have yet to fully embrace and adopt concepts of sustainable development such as systems for tracking, monitoring and adopting sustainable waste management practices intended to reduce, reuse and recycle their waste (Tudor 2008).

Tudor (2008) appears to agree with the AORCM (2014) and McGain et al (2010) finding that within healthcare organisations there has been little focus or attention on sustainability and waste/resource management, concluding that this has been regarded by these organisations as a low priority area.

Despite this assertion, it is clear that some healthcare organisations have made some effort to address this issue. For example, a diverse range of healthcare organisations such as acute care, mental health and primary care trusts participated in the RCN (2011) Freedom of Information report on waste management. However, the RCN (2011 p3) are clear that their report constitutes only a "snapshot" of the waste management practices with participating organisations. Furthermore, it could be argued that the methods used by the RCN might have been something of a blunt instrument in that they only reveal data on waste generated at an organisational level. As such, these methods could mask significant waste and or resource management issues within specific clinical areas, for example, in high dependency areas such as neonatal intensive care. It could be concluded that further, more detailed investigation of waste and resource management issues within these types of specific clinical areas is justified in order to inform interventions intended to enable sustainable changes in waste and resource management.

Such investigations and interventions are currently planned within a NNU in England in which quantitative data on the costs and emissions associated with the NNU waste management will be gathered along with qualitative data obtained from NNU staff on their knowledge, views, ability and willingness to implement sustainable waste management practices within their workplace, with the intention of cutting costs and enabling funding to be redirected into patient care.

\section{Conclusion}

This paper has reported on a systematic review of the literature that initially intended to investigate the management of waste generated with neonatal intensive care units. Limitations of the literature review should be acknowledged; it specifically looked for English language publications potentially ignoring other work on this topic published in other languages. The literature review also, despite its intention to do so, did not reveal "grey literature" on this topic. However, it could be argued that due to its nature this literature may be difficult to access. 
The literature review revealed a lack of available and published material specific to neonatology during an initial search of the literature and this required the focus of the literature review to be extended through two subsequent search phases to include broader areas such as paediatrics and intensive care. It was for this reason a third search was undertaken slightly altering the use of the search terms to assure the research team that it was unlikely that relevant papers had been missed. Despite these extensions of the search and broadening of its scope, little published material on waste management within neonatology or other similar high dependency and resource dependent clinical areas was found. This could be seen as a failing of the literature review. However, this lack of published material could also be seen as an indication that this is a relatively unexplored area of clinical practice that provides an opportunity for further empirical research and development of interventions within highly resource dependent areas such as neonatal intensive care that are intended to reduce waste costs and emissions whilst promoting a sustainable reduce, re-use, recycle philosophy within healthcare waste management. 


\section{References}

Academy of Medical Royal Colleges, 2014. Protecting resources, promoting value: a doctor's guide to cutting waste in clinical care. Academy of Medical Royal Colleges, London.

Luchetti, M., 2013. Intensive care resource allocation: when difficult choices have to be made. Br. J. Med. Pract. 6, (4):a633.

Manzi, S., Nichols, A., Richardson, J., 2014. A non-participant observational study of health and social care waste disposal behaviour in the South West of England. J Health Serv Res Policy. 19, (4) 231-235.

McGain, F., Story, D., Hendel, S., 2009. An audit of intensive care unit recyclable waste. Anaesthesia 64, (12) 1299-302.

NHS Sustainable Development Unit, 2012. Sustainability in the NHS health check 2012. Report, NHS Sustainable Development Unit, Cambridge.

National Institute for Health and Clinical Excellence (NICE), 2010. Quality Standards Programme. NICE cost impact and commissioning assessment: quality standards for specialist neonatal care.

Accessed 30/10/15.

https://www.nice.org.uk/guidance/qs4/resources/cost-impact-and-commissioningassessment-quality-standard-for-specialist-neonatal-care-252275437

Nichols, A., 2013. Sustainable family centred care in the neonatal unit. J Neonatal Nurs. 19, (5) 266-270.

Nichols, A., 2014. The impact of the clinical environment on family centred care in the neonatal unit: A qualitative investigation. J Neonatal Nurs. 20, (5) 230-235.

Royal College of Nursing, 2011. Freedom of Information report on waste management. Royal College of Nursing, London.

Richardson, J., Kagawa, F., Nichols, A., 2009. Health, energy vulnerability and climate change: A retrospective thematic analysis of primary care trust policies and practices. Public Health. 123, (12) 765-770.

Seidel, J., Whiting, P., Edbrooke, P., 2006. The costs of intensive care. Continuing Education in Anaesthesia. Crit Care Pain. 6, (4) 160-163.

Welton, J., Meyer, A., Mandelkehr, L., Fakhry, S., Jarr, S., 2002. Outcomes of and resource consumption by high-cost patients in the intensive care unit. Am J Crit Care. 11, (5) 467-473.

Wilkinson, D., 2013. Which newborn infants are too expensive to treat? Camosy and rationing in intensive care. J Med Ethics. 39, (8) 502-506. 
Tudor, T., Barr, S., Gilg, A., 2008. A Novel Conceptual Framework for Examining Environmental Behavior in Large Organizations A Case Study of the Cornwall National Health Service (NHS) in the United Kingdom. Environ Behav. 40, (3) 426450. 